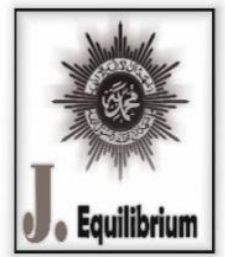

Equilibrium: Jurnal Pendidikan

Vol. IX. Issu 3. September-Desember 2021

\title{
Dampak Covid-19 Terhadap Karakter Remaja : Studi Kasus Remaja Usia 12-15 Tahun
}

\author{
Budhi Arti Laras Sukmawati ${ }^{1}$ dan Atiqa Sabardila ${ }^{2}$ \\ ${ }^{1}$ Pendidikan Bahasa dan Sastra Indonesia, Universitas Muhammadiyah Surakarta \\ Email: a310190128@student.ums.ac.id \\ ${ }^{2}$ Pendidikan Bahasa dan Sastra Indonesia, Universitas Muhammadiyah Surakarta \\ Email: as193@ums.ac.id
}

\begin{abstract}
The purpose of this study is to (1) describe perental assistance when at home durung the pandemic, (2) understand the character level of adolescents while at home, (3) provide solution that are applied to improve character. This research uses description by observsion and interviews. The collected data is then analyzed systematically and in detail then the results are presented in the from of narrative puzzles in ordinary words. The reselts of this study indicate that the character of adolescents and the potential for assistance carried out by parents in the application of the distance learning process to the difference between parents and different backgrounds, children's speesh and behavior, parents whwn at home are limited to seeing children's behavior, and parents are too busy with work so they can't provide assistance. The level of adolescent character while at home changes in a positive direction and in a negative direction. In this article, researchers provide solution that are offered to improve character during the deversity of assistance provided by parants affects the character of the child where thi time or opportunity for parents and children to speand a lot of time at home togerher.
\end{abstract}

Keywords : Covid-19; Mentoring; Character; Youth.

Abstrak. Tujuan penelitian ini untuk (1) memaparkan pendampingan orang tua ketika di rumah selama pandemi, (2) memahami tingkat karakter remaja selama di rumah, serta (3) memberikan solusi yang diterapkan untuk memperbaik karakter. Penelitiain ini menggunakan penelitian kualitatif yang bersifat diskriptif. Metode pengumpulan data dengan pengamatan dan wawancara. Data yang terkumpul kemudian dianalisis secara sistematis dan terperinci kemudian hasilnya disajikan dalam bentuk teks naratif dengan kata-kata biasa. Hasil penelitian ini menunjukkan bahwa karakter remaja serta proses pendampingan yang dilakukan orang tua dalam penerapan proses pembelajaran jarak jauh terdapat perbedaan antara orang tua serta latar belakang yang berbeda. Pendampingan yang dilakukan orang tua selama di rumah dapat dibedakan adalah orang tua ketika di rumah sangat memperhatikan anak dari ucapan dan tingkah laku anak, Orang tua ketika di rumah sebatas melihat perilaku anak, serta orang tua terlalu sibuk dengan pekerjaan sehingga tidak dapat memberikan pendampingan. Tingkat krakter remaja selama di ruah mengalami perubahan ke arah positif serta ke arah negatif. Dalam artikel ini peneliti juga memberikan solusi yang ditawarkan untuk memperbaiki karakter selama proses pembelajaran jarak jauh. Hal ini menunjukkan dari keragaman pendampingan yang diberikan oleh orang tua berbengaruh terhadap karakter anak dimana waktu atau kesempatan orang tua dengan anak banyak menghabiskan waktu di rumah bersama.

Kata Kunci : Covid-19; Pendampingan; Karakter; Remaja

\section{PENDAHULUAN}

Karakter berperan penting dalam kehidupan, karakter merupakan perilaku budi pekerti manusia yang khas, baik akhlak atau kepribadian yang berhubungan dengan Tuhan Yang Maha Esa, diri sendiri, sesama manusia, lingkungan dan kebangsaan dipergunakan sebagai cara pandang, berpikir, bersikap, berucap, bertingkahlaku, atau perbuatan berdasarkan norma-norma agama, hukum, tata krama, budaya dan adat istiadat yang berlakut di suatu daerah tertentu. Pendidikan karakter adalah seluruh 
usaha yang dapat dilakukan oleh pihak sekolah, orang tua, maupun masyarakat kepada anak-anak untuk membina, mendidik, serta mengembangkan karakter luhur budi pekerti sehingga anak dapat mengambil keputusan dengan bijak untuk dapat diwujudkan dalam kehidupan sehari-hari dan memberikan nilai kontribusi yang positif kepada lingkungan sekitar tempat tinggal (Purwanti, 2017)

Pendidikan karakter yang baik tidak hanya mencangkup aspek pengetahuai baik (moral Knowing), melaikan juga merasakan dengan baik, serta perilaku baik (moral action). Jadi pendidikan karakter kuat kaitanya dengan kebiasaan yang berulang atau terus-menerus dipraktekkan dan dilakukan dalam kehidupan (Komara, 2018). Pendidikan karakter dalam mencapai hasil yang diharapkan sesuai pengaplikasinnya, terdapat tiga faktor pendukung untuk mewujudkan tujuan yang dicita-citakan. Tujuannya (1) Pendidikan lingkungan keluarga, (2) Pendidikan lingkungan masyarakat, (3) Pendidikan lingkungan sekolah, (Julaeha, 2019). Pendidikan karakter diharapkan mampu memberikan dampak baik untuk kemajuan masyarakat bangsa dan negara dalam menjawab degradasi moral terkhusus pada remaja, serta pendidkan karakter dapat menjadi sebuah langkah yang harus ditempuh dalam membentuk karakter peserta didik yang berbudi pekerti luhur (Setiawan, 2021).

Saai ini dengan adanya Covid-19 sangat mempengaruhi karakter, kebijakan pemerintah untuk menanggulani penyebaran Covid-19 diantaranya pembatasan aktivitas, sosial distancing, hingga pembatasan mobilitas manusia dari wilayah ke wilayah lainya (Yulianingsih, 2021). Adanya kebijakan pemerintah sehingga sekolah terpaksa menerapkan pembelajaran jarak jauh, berdapak terhadap banyak penyimpangan dan perilaku negatif yang terjadi selama remaja jauh dari pendidikan sekolah secara langsung. Dimana pada saat sekolah lingkungan remaja masih dalam pengawasan guru, tetapi setelah adanya pandemi dan penerapan pembelajaran jarak jauh memberikan dampak yang cukup serius terhadap remaja. Terkhusus munculnya permasalahan pada diri remaja, permasalahanpermasalahan tersebut muncul karena lunturnya nilai-nilai karakter pada remaja karena kurangnya perhatian dari orang tua dan faktor lingkungan tempat tinggal.

Disadari jika meninggalkan pendidikan karakter disituasi semacam ini bukan termasuk dalam solusi, bahkan dengan meninggalkannya membuat karakter dan akhlak remaja semakin tidak terkendali. Serta jika remaja tidak segera mendapat penangganan, maka dapat dipastikan akhlak pada diri remaja tidak dapat berada pada posisi aman, dengan demikian perhatian yang diberikan oleh orang tua sangat dibutuhkan dalam pengembangan atau pemulihan karakter.

Sejatinya proses pemulihan dapat dilakukan oleh di rumah dengan pendampingan dengan usaha memperbaiki karakter. Peran orang tua untuk andil dalam proses pembelajaran daring dengan sabar dalam memberikan pendampingan dalam mengembangkan nilai-nilai karaker remaja (Munjiat, 2020). Dengan begitu secara perlahan karakter dapat kembali menjadi baik, tetapi jika orang tua tidak melakukan usaha maka kerusakan karakter menjadi permasalahan serius yang mengancam negara.

Peran orang tua dalam mendidik anak-anaknya tidak ada perbedaan, tetapi bagaimana orang tua dalm menjalankan peran mendidik anak adalah yang membedakan. Orang tua bebas dalam memilih metode, cara maupun pola asuh yang diterampan untuk anak-anaknya (Jannah \& Umam, 2020). Namun pada kenyataanya, pendidikan karakter yang sudah diusahakan belum dapat terlaksana dengan baik. Hal itu terlihat dari kenakalan remaja seperti perilaku perusakan fasilitas umum, pembullyan, pergaulan bebas bahkan sampai tawuran antar remaja, terkhusus pada masa pandemi. Maka peran orang tua dalam mendampingi sangat dibutuhkan.

Artikel ini bertujuan mengidentifikasi dampak covid terhadap karakter remaja di Dusun Pengin RW 2 Desa Cangkol, Mojolaban, Sukoharjo, Jawa Tenggah. Dimana pada masa pandemi ini karekter remaja mengalami penyimpangan, proses mengumpulan data dilakukan dengan terjun langsung kemasyarakat. Selain mengidentifikasi dampak terhadap karakter, artikel juga memberikan solusi yang dapat diterapkan untuk memperbaiki karakter. Dengan demikian diharapkan artikel ini mampu memberikan konstribusi secara langsung bagi orang tua dan pembaca sehingga penyimpangan karakter remaja dapat teratasi. 


\section{METODE PENELITIAN}

Penelitian ini termasuk pendekatan kualitatif, dengan proses penelitian yang digunakan adalah studi kasus. Teknik pengumpulan data melalui pengamatan dan wawancara. Penelitian dilaksanakan dengan mengumpulkan data telebih dahulu dari lapangan dimana tempat penelitian yaitu Dusun Pengin RW 2 Desa Cangkol Kecamatan Mojolaban Kabupaten Sukoharjo. Data penelitian yang telah didapatkan kemudian dilakukan analisis dengan cara mereduksi data sesuai dengan kebutuhan dari fokus peneliti. Data yang telah direduksi kemudia disajikan dan ditarik kesimpulan.

Peneliti dalam mendapatkan sumber informasi melalui beberapa orang dalam proses penelitian yakni: (1) orang tua: orang tua menjadi sumber informasi peneliti karena dari sepuluh orang tua peneliti mendapatkan informasi yang beragam dan dapat menyimpulkan bahwa proses yang dilakukan orang tua dalam mendidik berbeda. (2) Anak usia remaja: menjadi sasaran sumber informasi dimana peneliti mendapatkan langsung pada objek yang akan diteliti.

Metode wawancara dan pengamatan dilakukan dengan orang tua yang memiliki anak usia remaja sesuai dengan sasaran peneliti. Wawancara dilakukan dimana peneliti mendatanggi setiap rumah orang tua untuk mendapatkan informasi yang dibutuhkan. Dengan proses menanyakan langsung dengan orang tua dan melakukan pengamatan dengan remaja yang akan diteiti, maka proses penelitian dapat berjalan dengan baik dan mendapatkan data sesuai dengan kebutuhan.

\section{HASIL PENELITIAN DAN PEMBAHASAN}

\section{a. Pendampingan Orang Tua Ketika di Rumah Selama Pandemi}

Keluarga adalah salah satu lingkungan pendidikan, sehingga memungkinkan untuk melakukan proses pendidikan sebagai pendidikan in-formal dalam kehidupan sehari-hari (Syahputra, 2020). Dalam ruang lingkup kelurga pendidikan karakter perluh ditempuh untuk membentuk karaketer, dengan mendidik dan mengontrol anak di rumah terlebih dimana pandemi Covid saat ini yang merubah sistem memberlajaran menjadi online dari rumah. Dimana orang tua memiliki peran yang besar dalam pembentukan karakter anak, semua orang terlebih dalam lingkup keluarga disebabkan anak memiliki banyak waktu dirumah sehingga menjadikan orang tua sebagai pendidik utama dalam mengembangkan potensi anak dan mendidik dalam membentuk karakter.

Secara substansial lingkungan keluarga menjadi tempat tumbuh suburnya nilai-nilai karakter berbudi luhur dapar berubah menjadi tempat kekerasan yang mengekang kebebasan berkreativitas dan berinovatif. Ketika orang tua yang kurang melakukan pola asuh dengan baik tentu akan berdampak buruk bagi pertumbuhan maupun perkembangan anak kedepanya begitu sebaliknya. Maka dari itu pola asuh yang diterapkan orang tua harus dilaksanakan secara maksimal, melakukan pendampinan, keteladanan, dan kebudayaan serta nilai keagamaan, (Setiawan, 2021)

Berdasarkan hasil wawancara, pendampingan setiap orang tua selama di rumah memiliki perbedaan dalam menghadapi situasi anak dan lingkungan sekitar yang memengaruhi tumbuh kembang karakter anak

1. Orang tua ketika di rumah memperhatikan anak

Lingkungan keluarga menjadi tempat yang sangat strategis untuk menunjang peran orang tua yang utama dalam penanaman karakter dengan berbasis kesadaran diri, dengan adanya kesadaran diri dapat memberikan dampak bagi anggota keluarga berperan positif dalam menjalani kehidupan. Dengan menjadi orang tua yang baik dapat memberikan pengaruh dalam perkembangan anak dengan selalu mendampingi serta mengahargai setiap apa yang diusahakan anak dalam mengembangkan potensi untuk mencapai kebaikan dan dalam dirinya, (Setiawan, 2021)

Kesadaran orang tua mengenai pendampingan khusus dalam pembelajaran jarak jauh memang harus dikuasi oleh setiap orang tua, perbedaan proses pembelajaran menuntut orang tua harus paham dan mengerti akan kondisi serta situasi proses pembelajaran yang berlangsung supaya anak tidak ketinggalan pembelajaran. Secara prinsip, orang tua memiliki tanggung jawab untuk memelihara, mendidik, serta melindungi anak.

Pada pembelajaran jarak jauk dengan melibatkan orang tua dalam proses bembelajarannya diharapkan dapat menentukan perubahan karakter pada anak, dimana orang tua memiliki 
kesempatan baik terlibat langsung dalam pengawasan anak. Sehingga jika anak mengalami perubahan dapat terdeteksi dan langsung mendapatkan penangganan secara tepat.

Peran orang tua ketika di rumah memang melakukan pendampingan anak secara hati-hati, dimulai dengan berkomunikasi yang baik, memberikan kesempatan anak untuk berbicara dan terbuka, memberikan motivasi, serta mengarahkan anak dalam menyikapi permasalah mengenai pembelajaran maupun permasalahan-permasalahn yang dihadapi anak dalam pergaulan. Dengan begitu anak akan berada pada kondisi dimana pendidikan formal maupun karakter dapat tertata dengan baik.

Melakukan pendampingan dapat dilakukan orang tua selama berada di rumah, orang tua dapat memantau dengan siapa anak berteman ketika di rumah, apakah menggunakan gedget dengan baik, bahkan hingga memantau tugas-tugas sekolah sudah dikerjakan dengan baik. Hingga perubahan kecil pada karakter anak dapat dipantau oleh orang tua, sehingga orang tua secara langsung memberikan pengarahan untuk anak.

Pendampingan orang tua yang diberikan ketika di rumah dapat meningkatkan prestasi anak maupun masih menerapkan pembelajaran jarak jauh. Meskipun pada dasarnya orang tua memiliki kesibukan dalam pekerjaan, pendampingan tersebut tetap dapat berjalan jika orang tua memiliki kesadaran dalam melakukan pendampingan terutama anak pada masa pertumbuhan.

2. Orang tua ketika di rumah sebatas mengetahui perilaku anak

Pendampingan orang tua sangat penting karena memberikan pengaruh besar terhadap keberhasilan anak. Dengan Pendampingan orang tua, maka anak akan lebih mudah dalam melakukan perkembangan literasi, motivasi, dan prestasi. Namun sebaliknya, jika anak tidak mendapat pendampingan dan bimbingan dari orang tua tidak akan dapat berjalan dengan sendirinya. (Yulianingsih et al., 2021)

Orang tua sebatas mengetahui perilaku anak selama di rumah, dimana orang tua memberikan sedikit kebebasan untuk anak dalam mengatur dirinya sendiri, orang tua yang hanya tau bahwa ketika anak fokus dengan gedged berarti anak sedang menyelesaikan tugas sekolah. Orang tua merasa anak aman jika hanya berada didalam rumah, padahal bahaya sesungguhnya berada pada diri anak sendiri jika orang tua tidak melakukan pendampingan.

Pengaruh dari gadged jika terus dibiarkan akan berdampak serius untuk perkembangan anak, ketika kebebasan menggunakan gedged tidak dibatasi maka bisa terjadi anak mengalami ketergantungan dengan bermain gadget dan akan mengabaikan dalam mengerjakan tugas serta anak bisa saja tidak mengikuti kelas selama pembelajaran jarak jauh.

Minimnya pendampingan dari orang tua menyebankan anak mengalami kurang perhatian sehingga menyebabkan perubahan karakter yang dapat dilihat, perubahan karakter yang dapat dilihat seperti menunda kewajiban, menutup diri atau bahkan sampai tidak memperhatikan kondisi sekitar karena terlalu fokus pada gedged.

Melihat masih rendahnya pemaham peran orang tua dalam pendampingan mengakibatkan anak menjadi korban, tanpa disadari jika hal ini tidak mendapatkan penanganan yang serius maka perubahan karakter anak dapat menjadi kritis. Selain itu, kondisi lingkungan dan budaya masyarakat sekitar tempat tinggal dapat memempengaruhi rusaknya moral atau karakter anak terutama pada usia remaja.

3. Orang tua telalu sibuk dengan pekerjaan sehingga tidak dapat memberikan pendampingan.

Peran orang tua menjadi sangat penting untuk menyukseskan pembelajaran online. Situasi dilematis terjadi ketika orang tua tidak dapat mendampingi anak karena sibuk bekerja. Mereka adalah orang-orang yang tidak dapat bekerja dari rumah. Buruh pabrik, pekerja kesehatan, pekerja informal harus tetap bekerja. Begitu orang tua sibuk dengan pekerjaan sementara mereka tidak memiki orang lain yang dapat membantu mendampingi anak, (Suasthi \& Suadnyana, 2020)

Pengaruh besar dari karater sesorang adalah lingkungan keluarga, jika orang tua salah dalam pengasuhan serta pendampingan maka anak akan mengalami perilaku-perilaku yang tidak baik. Kesibukan orang tua dengan pekerjaan membuat mereka lupa dengan kewajiban dalam mendidik anak, orang tua dengan berpendapat bahwa fasilitas pembelajaran dan kebutuhan anak tercukupi anak mampu dalam mengontrol diri terutama di usia remaja. Tapi pada kenyataanya anak melakukan 
penyimpangan serta tidak jarang banyak anak yang menentang orang tua dengan berperilaku semaunya, hal ini disebabkan karena anak tidak mendampatkan pendampingan yang baik.

Sedangkan untuk para orang tua yang memiliki kesempatan bekerka dari rumah tetapi memprioritaskan pekerjaan kantor dan tidak dapat melakukan pendampingan belajar secara optimal, (Suasthi \& Suadnyana, 2020). Orang tua dengan memperioritaskan pekerjaan dari pada pendampingan anak menyebabkan proses belajar jarak jauh mengalami tekendala, dimana anak kurang mendapatkan perhatian dan mencari pelarian untuk menyenangkan diri berpengaruh kepada anak dalam melakukan hal-hal negatif di lingkungan masyarakat sebagai bentuk pelampiasan terhadap kesendirian selama berada di rumah.

Perilaku anak dapat dengan mudah terpengaruh dari lingkungan luar atau pergaulan bebas yang mengakibatkan lunturnya nilai-nilai karakter, apabila dengan minimnya pendampingan orang tua terutama pada masa pertumbuhan. Maka diharapkan peran orang tua disini penting dalam melakukan pendampingan, memberikan motivasi, dan teladan yang baik untuk anak.

\section{b. Tingkat Karakter Remaja Selama di Rumah}

Selama pembelajaran menggunakan sistem jarak jauh dapat mempengaruhi karakter anak dalam kehidupan sehari-hari, perubahan karakter dapat terjadi ke arah positif dan juga ke arah negatif

1. Perubahan ramaja ke arah positif

Dalam proses pembelajaran jarak jauh terkhusus pada pendidikan karakter di masa pandemi ini telah mendorong kemandirian belajar remaja dan membentuk karakter yang bertanggung jawab terhadap materi dan tugas-tugas pelajaran yang diberikan oleh guru melalui pembelajaran online yang dilaksanakan dari rumah masing-masing.

Lingkungan keluarga sebenarnya menang merupakan lingkungan yang baik untuk melakukan proses perkembangan atau pemulihan moral atau karakter positif anak. (Purandina \& Winaya, 2020). Peran orang tua memberikan pengaruh yang besar dalam memberikan perubahan karakter anak, pendampingan anak dengan diperhatikan kondisi dan orang tua menganggap keberadaan anak akan diterima serta diakui membuat anak nyaman, kebutuhan pokok terpenuhi maka karakter anak dapat berkembang dengan baik.

Kondisi dimana remaja ketika watku yang dimiliki dapat dihabiskan hanya di rumah sehingga mendapatkan langsung pendampingan dari orang tua, dengan begitu anak mendampatkan pembelajaran sesuai dengan apa yang dibutuhkan. Upaya orang tua dalam melakukan pendampingan untuk mempertahankan karakter anak adalah usahan yang dapat ditempuh untuk para orang tua.

Dampak positif yang dialami anak selain memiliki rasa tanggung jawab adalah memiliki jiwa sosial yang tinggi, anak di rumah dapat mengembangkan potensi yang dimiliki dalam kehidupan masyarakat, disamping mengembangkan potensi yang dimiliki anak juga mendapatlan kenyamanan dalam menjalankan proses pembelajaran jarak jauh.

Dalam pembelajran jarak jauh ketika anak mendapatkan motivasi dari orang tua yang menunjukkan bentuk pengembangan sikap etika, moral, dan tanggung jawab terhadap diri sendiri dan lingkungan sekitar. Dengan begitu anak dapat membiasakan diri dalam kehidupan terutama bagi remaja untuk bekal kehidupan secara terarah.

2. Perubahan remaja ke arah negatif

Kebanyakan orang tua menganggap keterlibatan mereka dalam pendidikan anak hanya sebatas menanggung biaya, menyediakan infratruktur dan menyediakan keperluhan materi lainya. Tetapi dalam konteks pendidikan, keterlibatan orang tua harus menyatu dengan lingkup yang lebih luas dari pada sekedar masalah pembiayaan semata. (Yulianingsih el al., 2021). Keterlibatan dan pendampingan orang tua dalam lingkup pendidikan sangat dibutuhkan anak untuk menunjang proses pembelajaran.

Anak ketika tidak mendapatkan pendampingan secara baik dari orang tua dapat memberikan dampak yang cukup serius dalam pertumbuhan karakter, dimana anak memiliki karakter yang menyimpang serta mengalami kerusakan moral yang jauh dari kata baik, dampak negatif yang dialami anak selama mengalami kurangnya pendampingan dari orang tua dengan proses pembelajaran jarak 
jauh yang menghabiskan waktu dirumah membuat anak menjadi anak rumahan dengan kurang beriteraksi dengan teman seumuran atau dengan tentangga sekitar.

Pengaruh globaliasi juga berdampak pada pergaulan remaja, dampak dari globalisasi dapat mempengaruhi perubahan sikap, perilaku, dan moral yang buruk pada kepribadian remaja (Hasibuan el al, 2018). Pembelajaran jarak jauh yang memaksa anak menggunakan gadjed dapat memberikan pengaruh yang signifikan jika penggunaan gedjed secara berlebihan, ketika anak tidak dapat mengontrol maka gadjed berdampak pada kecanduan dan sulit untuk dilepaskan dari anak. Begitu juga dengan anak yang sering keluar malam untuk berkumpul dengan teman sampai larut malam, perlahan anak melupakan tugas sekolah dan dengan terbuka menerima ajakan teman untuk tidak mengerjakan tugas. Dengan begitu membuat anak sulit mendapatkan nasihat dari orang tua.

Dengan adanya ketidak seimbangan serta anak dibiarkan dalam mendapatkan bimbingan yang diberikan oleh orang tua karena orang tua terlalu sibuk dengan pekerjaan, dapat membuat karakter anak menjadi rusak bahkan moral yang ada pada diri anak jika terus dibiarkan tanpa mendapatkan pendampingan khusus maka anak sulit untuk megenali diri sendiri.

\section{c. Solusi Yang Dapat Diterapkan Untuk Memperbaiki Karakter}

Solusi untuk mengembalikan atau memperbaiki karakter anak dapat dilakukan dengan pendampingan orang tua, dengan orang tua meluangkan waktu untuk mendampingi proses pertumbuhan anak dan proses belajar sangat memperngaruhi karakter. Meskipun orang tua memiliki kesibukan tetapi dalam mendidik anak tetap diutamakan, dengan demikian orang tua dapat melakukan usaha untuk mengebalikan atau mempertahankan karakter anak sebagai berikut:

1. Memberikan pendampingan dan moivasi agar anak lebih merasa diperhatikan

Peran orang tua sangat berpengaruh dalam keluarga untuk menciptakan emosional dengan anak, orang tua juga dapat menciptakan suasana aman di rumah sehingga rumah merupakan tempat anak kembali. Dengan demikian anak akan merasa senang dan tenang ketika dirumah dan membuat anak menjadi terbuka kepada orang tua.

Kesibukan orang tua dengan pekerjaan tidak sepantasnya melupakan kewajiban dalam melakukan pendampingan atau pendidikan untuk anak. Dimana orang tua sebagai madrasah pertama anak di dalam lingkup keluarga. Serta dalam proses pembelajaran jarak jauh mebuat anak kehilangan kesempatan belajar bersama guru maupun temannya.

Proses pembelajaran dengan menyesuaikan kondisi dan situasi dimana sekolah diliburkan dan berubah menjadi belajar di rumah, dalam kondisi seperti ini peran orang tua dalam mendampingi pembelajaran anak sangat dibutuhkan, dengan anak mendapatkan pendampingan dan motivasi secara cukup serta nasihat yang diberikan ketika anak melakukan kesalahan, sehingga motivasi dan pehatian orang tua dapat memberikan dapak yang positif untuk kemajuan prestasi anak selama belajar dirumah.

2. Memberikan contoh perubahan dari hal terkecil yang membuat anak menjadi sadar akan tanggung jawabnya, misal mengajak sholat tepat waktu.

Dalam lingkungan keluarga, apa yang dilakukan oleh orang tua melalui perbuatan dan ucapan yang keluar dari mulut dapat diikuti oleh anak, seakan sebagai panutan untuk anak dalam bersikap seperti apa yang orang tua perbuat, maka orang tua diharapkan bertingkah laku dan berucap dengan baik agar anak juga melakukan sesuatu kebaikan. Karakter yang baik didukung oleh ilmu atau pengetahuan tentang kebaikan, keinginan untuk berbuat baik dan melakukan perbuatan kebaikan.

Karakter pada anak melekat yang tercermin pada pola perilaku dalam kehidupan sehari-hari. Faktor lingkungan dan faktor bawahan dapat mempengaruhi perilaku, dalam faktor lingkungan sebagai faktor eksternal yang dapat membentuk karakter, maka pendidikan menjadi sangat penting. Karakter anak merupakan hasil interaksi antara lingkungan dan pembawan, sehingga dalam penguatan karakter yang ditekankan adalah intekasi pembawaan dan lingkungan yang mempengaruh, (Khamalah, 2017) 
Dengan pendidikan orang tua mampu memberikan pengarahan atau pengampingan kepada anak. Dimana anak akan mampu memberikan hal-hal positif dan tidak bertentangan dengan nilai-nilai karakter.

3. Melibatkan anak untuk melakukan pekerjaan rumah

Karakter anak dapat dikembangkan dengan cara pendampingan melalui nilai-nilai yang terkandung dalam kehidupan masyarakat dan dapat dilanjutkan dengan menginternalisasikan dalam diri sendiri untuk menjadikan kebiasaan berperilaku sehari-hari. Karena, karakter sebenarnya lebih menonjolkan pada tingkahlaku dibandingkan pada pengentahuan, (Ramdani, 2018)

Disamping orang tua memberikan contoh, tanggung jawab, dan motivasi. Orang tua juga dapat memberikan kesempatan atau melibatkan anak dalam berbagai bentuk kegiatan dirumah. Dengan memberikan kesempatan atau melibatkan anak dalam berbagai bentuk kegiatan di rumah dapat memperkuat ikatan anak dengan orang tua, membuat keduanya menjadi dekat dan hubungan menjadi harmonis.

Kerja sama antara orang tua dan anak harus dipererat, dijalin dengan baik dengan terus membangun koordinasi terkait dalam upaya pembentukan karakter anak. Sebagai contoh kerja sama dalam membersihkan rumah dapat melatih anak akan tanggung jawab serta anak merasa dekat dengan orang tua.

Dengan kedekatan anak dan orang tua, tingkat nilai dan karakter anak dapat dikendalikan. Dengan demikian pengaruh atau faktor penghabat dapat diantisipasi orang tua, sehingga anak dapat terkontrol dalam pendampingan orang tua ketika pelaksanaan sekolah masih mengunakan sistem jarak jauh.

\section{Pembahasan}

Setiap individu harus memahami mengenai karakter, baik bagi calon orang tua maupun yang sudah menjadi orang tua. Masing-masing setiap orang tua memiliki tanggungjawab dalam mendidik anak terutama dalam proses pendidikan karakter di lingkungan keluarga bagi seluruh anggota keluarga. Peran keluarga sebagai lembaga pendidikan semakin penting terutama peran keluarga dalam melakukan pendampingan penanaman sikap dan nilai hidup selama pembelajaran jarak jauh berlangsung di masa pandemi, (Rosanti, 2021)

Keluarga memiliki peran yang strategis dalam pendidikan anak dan merupakan lembaga pendidikan pertama dalam kehidupan anak, tempat belajar dan berkembang sebagai manusia yang utuh serta makhluk sosial. Selain itu keluarga juha menjadi tempat pertama dalam mengenai aturan yang berlaku di lingkungan keluarga dan masyarakat. Di lingkungan keluarga pula anak-anak mengenal sosok panutan, yakni kedua orang tua yang paling bertanggung jawab dalam mendidik serta melakukan pendampingan dalam proses tumbuh kembang anak, (Afrilia \& Indriya, 2020)

Saat ini, dalam menemui perang orang tua yang maksimal untuk melakukan pendampingan di lingkungan keluarga terasa sulit, karena kebanyakan orang tua lebih mementingkan pekerjaan dan kariernya, sehingga orang tua tidak memiliki kesempatan bersama anak yang cukup untuk berinteraksi dengan anak di rumah, padahal pendampingan didapatkan melalui interaksi yang intensif antara anak dengan orang tua. (Munawaroh, 2019)

Sejauh ini, orang tua dalam melakukan pendampingan yang kurang serius terkait pada mentalitas anak. Sebagaian orang tua memiliki sikap apatis bahkan mebiarkan anak tumbuh dalam kesendirian. Masalah inilah yang dihadapi saat ini yaitu kurangnya pendampingan dan keteladanan orang tua. Padahal, pendidikan karakter dan humaniora (Kemanusiaan) menjadi salah satu jalan untuk menyelesaikan permasalahan yang ada.

Namun tidak semua orang tau bersikap apatis dalam melakukan pendampingan terhadap anak. Ada orang tua yang memang benar-benar memperhatikan anak, memeberikan motivasi, serta pengarahan dalam proses pembelajaran atau permalasalah yang sedang dihadapi anak. Upaya yang dilakukan orang tua untuk lebih memberikan perhatian untuk anak akan memberikan dampak yang posif dalam nilai-nilai karakter. 
Pada pembelajaran jarak jauh ini lebih ditekankan pada pendidikan karakter oleh orang tua, (Mubin, 2020). Tugas dalam mendidik anak bukan hanya dimiliki atau dipelajari oleh para guru akan tetapi orang tua sebagai madrasah utama dalam lingkungan keluarga memiliki peran yang sama dalam mamahami strategi untuk mengajar anak agar dapat mendidik dan mengarahkan menjadi baik dan benar.

Selain itu pendidikan karakter yang diberikan orang tua dapat mengembangkan kepribadian anak agar bersifat jujur, bertanggungjawab, adil, pekerja keras dan nilai karakter-karaktr unggul lainnya. Memberika cohtoh dalam membiasakan untuk mempraktekkan dalam kehidupan nyata sehari-hari akan membatu tercapainya tujuan yang diterapkan orang tua, (Abdusshomad, 2020).

Orang tua berusaha memberikan pendampingan berupa perilaku terpuji kepada anaknya, maka anak akan meniru perilaku tersebut dalam kehidupan sehari-hari. Tetapi jika orang tua dalam memberikan pendampingan dengan perilaku yang tidak terpuji maka anak akan mengikuti bentuk perilaku tidak terpuji juga, (Munawarog, 2019)

\section{KESIMPULAN}

Berdasarkan hasil penelitian dan pembahasan mengenai dampak Covid-19 terhadap karakter remaja Dusun Pengin RW 2 Desa Cangkol Kecamatan Mojolaban Kabupaten Sukoharjo. Maka dapat disimpulkan bahwa cara pendampingan orang tua dalam mendampingi anak di rumah untuk mengendalikan karakter anak terdapat perbadaan antara orang tua walaupun waktu atau kesempatan orang tua dengan anak banyak menghabiskan waktu bersama. Serta mengetahui tingkat karakter yang selama di rumah dan solusi yang ditawarkan untuk memperbaiki karakter. Dengan demikian peran orang tua sangat berpengaruh terhadap perkembangan perilaku dan nilai-nilai karakter terkhusus pada anak ramaja.

\section{DAFTAR PUSTAKA}

Abdusshomad, Alwazir. 2020. Pengaruh Covid-19 Terhadap Penerapan Pendidikan Karakter dan Pendidikan Islam. Jurnal Pendidikan, Sosial, dan Agama, 12 (2), 107- 115. https://doi.org/10.37680/qalamuna.v12i2.407

Afrilia, Hilda \& Indriya, 2020. Internalisasi Pendidikan Karakter Islam Anak Ditengah Pandemi Covid19. Jurnal Pendidikan Islam, 6 (2), 46-52. https://jurnaltarbiyah.stainsorong.ac.id/index.php/alfikr

Hasibuan A. Abdul dkk. 2018. Manajemen Pendidikan Karakter di SMA (Studi pada SMAN dan MAN di Jakarta). Jurnal Keilmuan Manajemen Pendidikan, 4 (2), 191-212. http://jurnal.uinbanten.ac.id/index.php/tarbawi

Hendayani, Meti. 2019. Problematika Pengembangan Karakter Peserta Didik di Era 4.0. jurnal Penelitian Pendidikan Islam, 7(2), 184-198. https://doi.org/10.36667/ippi.v7i2.368

Jannah, Nur \& Umam, Khairul. 2021, Peran Orang Tua Dalam Pendidikan Karakter Berbasis Keluarga di Masa Pandemi Covid-19. 12 (1), 95-115

Julaeha, Siti. 2019. Problematika Kurikulum dan Pembelajaran Pendidkan Karakter. Jurnal Penelitian Pendidikan Islam, 7 (2), 158-182. https://doi.org/10.36667/jppi.v7i2.367

Khamalah, Nur. 2017. Penguatan Pendidikan Karakter di Madrasah. Jurnal Kependidikan, 5 (2), 200215. https://doi.org/10.24090/jk.v5i2.2109

Komara, Endang. 2018. Penguatan Pendidikan Karakter dan Pembelajaran Abad 21. Jurnal Sipatahoenan, 4 (1), 17-26. www.journals.mindamas.com/index.php/sipatahoenan

Mubin, S. Mohammad. 2020. Pendidikan Karakter Menurut Ibnu Miskawaih dan Implementasi Terhadap Pembelajaran Masa Pandemi. Jurnal Pendidikan dan Pembelajaran, 9 (2), 144-130

Munawaroh. 2019. Keteladanan Sebagai Metode Pendidikan Karakter. Jurnal Penelitian Pendidikan Islam, 7 (2), 142-156. https://doi.org/10.36667/ippi.v7i2.363

Munjiat M. Siti. 2020. Analisis Upaya Orang Tua Dalam Mendidik Anak Dimasa Pandemi. Jurnal $\begin{array}{lllll}\text { Pendidikan dan } & \text { Studi } & \text { Islam, 230-342. }\end{array}$ https://jurnal.faiunwir.ac.id/index.php/Jurnal Risalah 
Purandina, Y. I Putu \& Winaya, A. I Made. 2020. Pendidikan Karakter di Lingkungan Keluarga Selama Pembelajaran Jarak Jauh pada Masa Pandemi COVID-19. Jurnal IImu Pendidikan. 3 (2), 270-290. https://doi.org/10.37329/cetta.v3i2.454

Purwanti, Dwi. 2017. Pendidikan Karakter Penduli Lingkungan dan implementasinya. Jurnal Riset Pedagogik, 1 (2), 14-20. https://jurnal.uns.ac.id/jdc

Ramdani, Emi. 2018. Model Pembelajaran Kontekstual Berbasis Kearian Lokal Sebagai Penguagtan Pendidikan Karakter. Jurnal Pendidikan IImu-ilmu Sosial, 10 (1), 1-10. http://jurnal.unimed.ac.id/2012/index.php/iupiis

Rosanti, Atik. 2021. Manajemen Pendidikan Orang Tua pda Masa Corona Virus Diseases 2019 (COVID19) dalam Peningkatan Kecerdasan Emosional dan Karakter Anak Berdasarkan pada Tingkat Pendidikan Orang Tua di SDN 1 Selajambe Kabupaten Kuningan. Jurnal Ilmiah Dozen Globalindo, 1 (3), 23-28

Sari, K. Nona dkk, 2020. Strategi Penanaman Karakter Islam pada Siswa MTS Swasta Al Manar Medan Johor (Studi Kasus Selama Daring). Jurnal Pendidikan Islam, 1 (3), 147-164. https://creativecommons.org/licenses/by-sa/4.0/

Setiawan, Agus. 2021. Pendidikan Karakter pada Peserta Didik di Masa Pandemi Covid-19 Berbasis Keluarga. Jurnal Ilmiah Mandala Education, $7 \quad$ (1), 319-327. http://ejournal.mandalanursa.org/index.php/JIME/index

Suasthi, A. I Gusti \& Suadnyana, E. P. B. Ida. 2020. Membangun Karakter "Genius" Anank Tetap Belajar Dari Rumah Selama Pandemi Covid-19 Pada Sekolah Suta Dharma Ubud Gianyar. Jurnal IImu Pendidikan, 3 (3), 431-451. http://jayapanguspress.penerbit.org/index.php/cetta

Syahputra C. Muhammad. 2020. Pendidikan Orang Tua Terhadap Anak dalam menyikapi Pandemi COVID-19. Jurnal

Equalita, 2

(1),

59-66. http://syekhnurjati.ac.id/jurnal/index.php/equalita/article/view/6364

Yulianingsih, Wiwin dkk. 2021. Keterlibatan Orangtua dalam Pendampingan Belajar Anak Selama Masa Pandemi Covid-19. Jurnal Pendidikan Anak Usia Dini, 5 (2), 1138-1150. http://doi.org/https://doi.org/10.31004/obsesi.v5i2.740 